\title{
Ankarana-a rediscovered nature reserve in northern Madagascar
}

\author{
Jane M. Wilson, Paul D. Stewart and Simon V. Fowler
}

Over the centuries the Ankarana Massif has been home to at least 12 lemur species, reflecting the incredible ecological wealth and diversity of this small forest reserve. Yet almost no systematic biological work had been done there, until the Southampton University team (supported by the Oryx $100 \%$ Fund) visited Ankarana in 1981. Oryx published a report of this expedition in January 1987. A new team of nine British biologist-cavers, three doctors, two Malagasy palaeontologists, an entomologist and a botanist spent the end of the 1986 dry season (mid-August to mid-October) producing the first catalogue of the fauna and flora. The team rediscovered the rare white-breasted mesite, an endemic bird last seen at Ankarana in 1931 and known from only two other small areas in Madagascar; special efforts were also made to assess the conservation status of lemurs, bats and the Nile crocodiles, which have refuges there.

Ankarana is a small $(28 \times 8 \mathrm{~km})$ limestone massif lying about $75 \mathrm{~km}$ south of Antsiranana (DiégoSuarez) in the extreme north of Madagascar (Figure 1). It is an 'island' of $182 \mathrm{sq} \mathrm{km}$ of pinnacle karst and semi-deciduous dry tropical forest surrounded by savannah, which grows on basalt. It was designated the Réserve Spéciale d'Ankara (sic) in 1956 (Andriamampianina, 1984), but its reserve status is unknown locally and overlooked nationally. There is no warden and no control of timber felling.

Numerous canyons, some $200 \mathrm{~m}$ deep, penetrate the massif, but the dense forest or tangled scrub within them makes the process of exploration and biological survey difficult. Old logging trails provide easier routes to the centre of the massif, otherwise access is by climbing over the top of the limestone, which has been eroded into spectacular razor-sharp ridges and pinnacles locally called tsingy. Progress on the tsingy is slow, dangerous and soon damages clothes, boots and hands. In some places vast caves have collapsed to allow pockets of isolated, lush, river-fed forests. These are in closed depressions up to $200 \mathrm{~m}$ deep and $1 \mathrm{~km}$ across. We gained access only to some of these either by rock climbing Ankarana - a rediscovered nature reserve or by way of the $98 \mathrm{~km}$ of cave passages that riddle the massif. Although there is no formal protection of the reserve, access to some small forest pockets is so difficult that it is hard to see

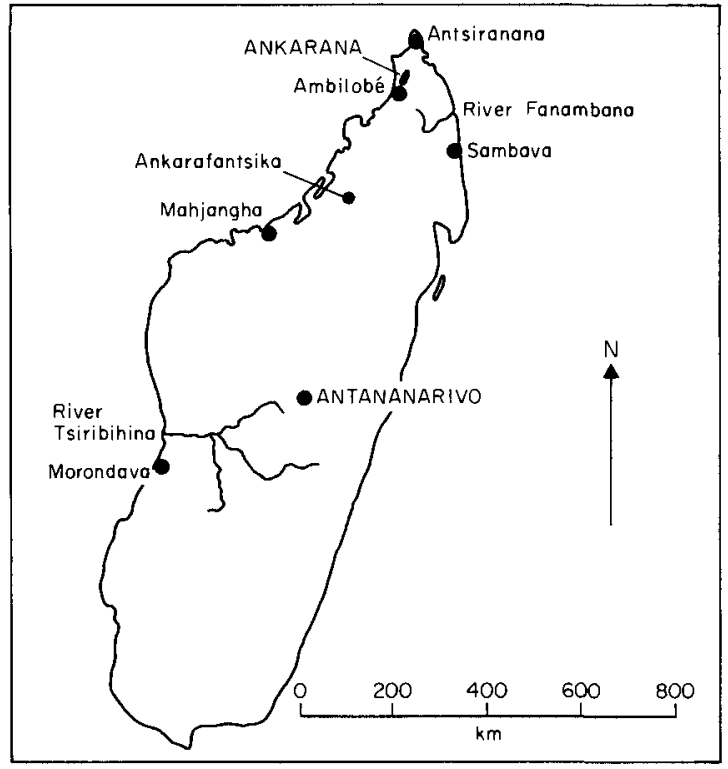

Figure 1. Map of Madagascar showing places mentioned in the text. 
how they might ever be exploited. Sadly, however, the richest and largest forest patches are accessible and, therefore, at risk. Further details on the ecology of Ankarana are given by Chapman et al. (1987).

\section{Lemurs}

The lemur most in evidence in the canopy forests of Ankarana is the attractive, agile and adaptable crowned lemur Lemur coronatus, so called because the brown male has a triangle of black fur between his ears. The larger female is less strikingly marked and is a soft grey colour. In midSeptember we noted the appearance of the first few-day-old infants clinging to their mother's belly fur. The crowned lemur is not yet fearful of man there since it is protected by local fady (taboo) against hunting. It seems to be thriving at Ankarana, indeed our estimates of population density of up to 5 adults per hectare in the canopy forests are high compared with other forest primates of similar size (Bourlière, 1985; Robinson and Redford, 1986).

Ankarana is the westernmost extent of its range. It is found no further south than the Fanambana River, which lies less than $200 \mathrm{~km}$ from the northern tip of Madagascar (Tattersall, 1982). Thus, the crowned lemur has a tiny range (a rectangle of about $70 \times 170 \mathrm{~km}$, which probably now contains little suitable habitat) and even this small area is shrinking. A few years ago these lemurs could be seen stealing from dustbins in the town and port of Antsiranana, but hunting by nonMalagasy people who do not observe fady has caused the disappearance of the lemurs from the town (B. LeNormand, pers. comm., 1986). Lemurs of the Montagne d'Ambre National Park (Figure 2), less than $30 \mathrm{~km}$ away, are extremely timid for they are hunted, despite the fact that the park is wardened. Benjamin LeNormand, a French teacher, is working to introduce crowned and other threatened lemur species to an uninhabited island, Nosy Hara, in the hope that they will be safe there until a properly protected reserve exists (Figure 2).

The other predominantly diurnal lemur at Ankarana is Sanford's lemur, Lemur fulvus sandfordi. Petter et al. (1977) state that this northern subspecies is common as far south as Sambava, but more recent surveys (Tattersall, 164
1982) suggest that Sanford's lemur has a minute range similar to its crowned relative. Like the crowned lemur, Sanford's lemur is also present in substantial numbers at Ankarana, although it seems to favour secondary (degraded) forest or forest bordering the savannah surrounding the massif. During the dry season these two Lemur species can be seen tolerantly feeding together in the same tree, eating fruits of lianas: Strychnos spp., and Landolphia perrieri, as well as of the ebony Diospyros sp. In degraded forest, Sanford's lemurs feed on a wider variety of plants, probably including the introduced tamarind tree Tamarindus indica, which has become established at Ankarana. A more detailed description of the ecology of the lemurs is given by Wilson et al. (1987).

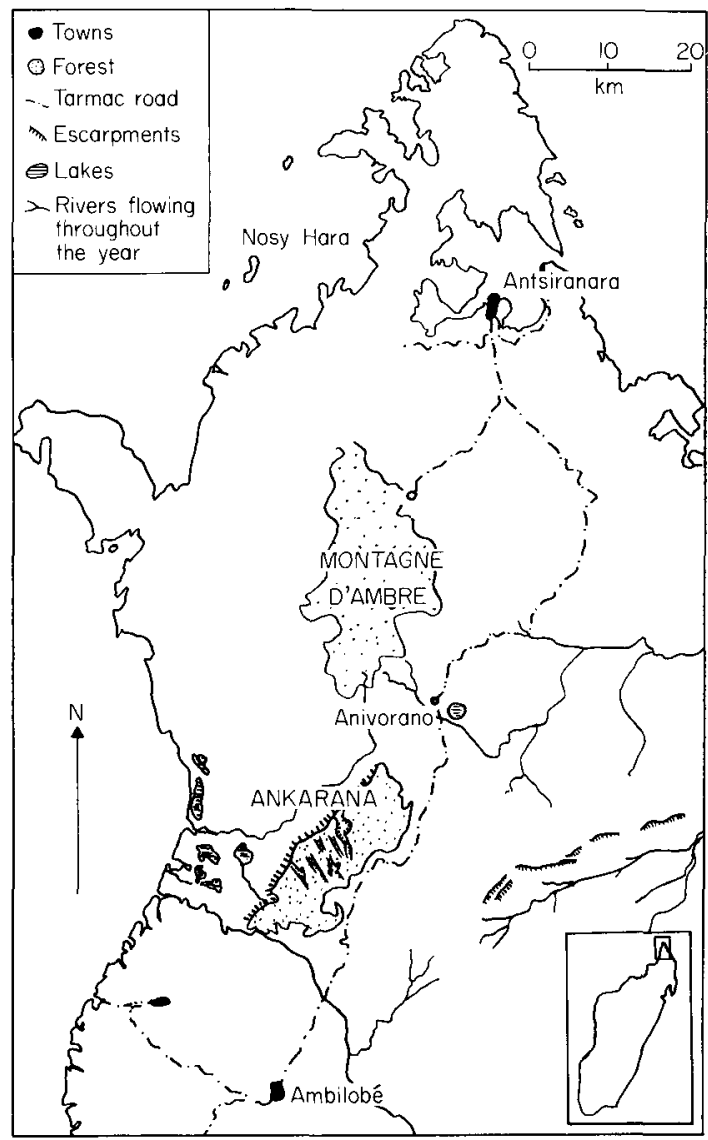

Figure 2. Map of northern Madagascar showing location of Ankarana Massif and Montagne d'Ambre.

Oryx Vol 22 No 3, July 1988 


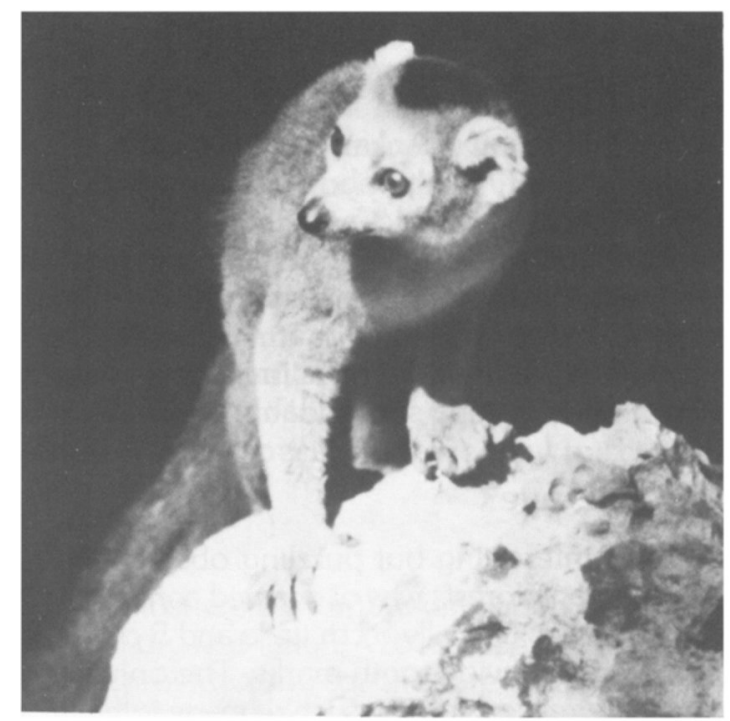

Male crowned lemur emerging from the Second River Cave waterhole (Jane Wilson).

The solitary nocturnal, folivorous sportive lemur Lepilemur septentrionalis ankaranensis is common at Ankarana, in the most diverse and productive canopy forest. Where they achieved their highest densities, their reflected eyeshines showed one Lepilemur approximately every 30$100 \mathrm{~m}$. The eastern woolly lemur Avahi laniger laniger, the greater dwarf lemur Cheirogalus major, and the grey mouse lemur Microcebus murinus, are also said to live at Ankarana (G.-S. Ramanagason, pers. comm., 1986).

\section{The greater bamboo lemur and other sub-fossils}

The sub-fossilized skeleton of a greater bamboo or broad-nosed gentle lemur Hapalemur simus, was found near a forested cave entrance of $L a$ Grotte d'Andrafiabe by the 1981 team. Museum specimens then totalled about 15 worldwide (Vuillaume-Randriamanantena et al., 1985). This is the world's second rarest lemur, after the hairyeared dwarf lemur Allocebus trichotis. Hapalemur simus was once found in western, northern and central Madagascar, but is now known from only 60-80 individuals that survive in the east in a patch of degraded forest near Ranomafana, $1000 \mathrm{~km}$ south of Ankarana (B. Meier, pers. comm., 1986).

Ankarana - a rediscovered nature reserve
We returned to the site of this important discovery with Malagasy palaeontologists, Drs VuillaumeRandriamanantena and Ralaiarison-Raharizelina, to look for further skeletons and to investigate the possibility that the species has a relict population at Ankarana. Within La Grotte d'Andrafiabé we found a further 18 skeletons, as well as bones of the diadem sifaka Propithecus diadema (previously unknown from Ankarana) and those of Mesopropithecus, a large extinct lemur, which Dr Randriamanantena believes moved more like an African potto Perodicticus

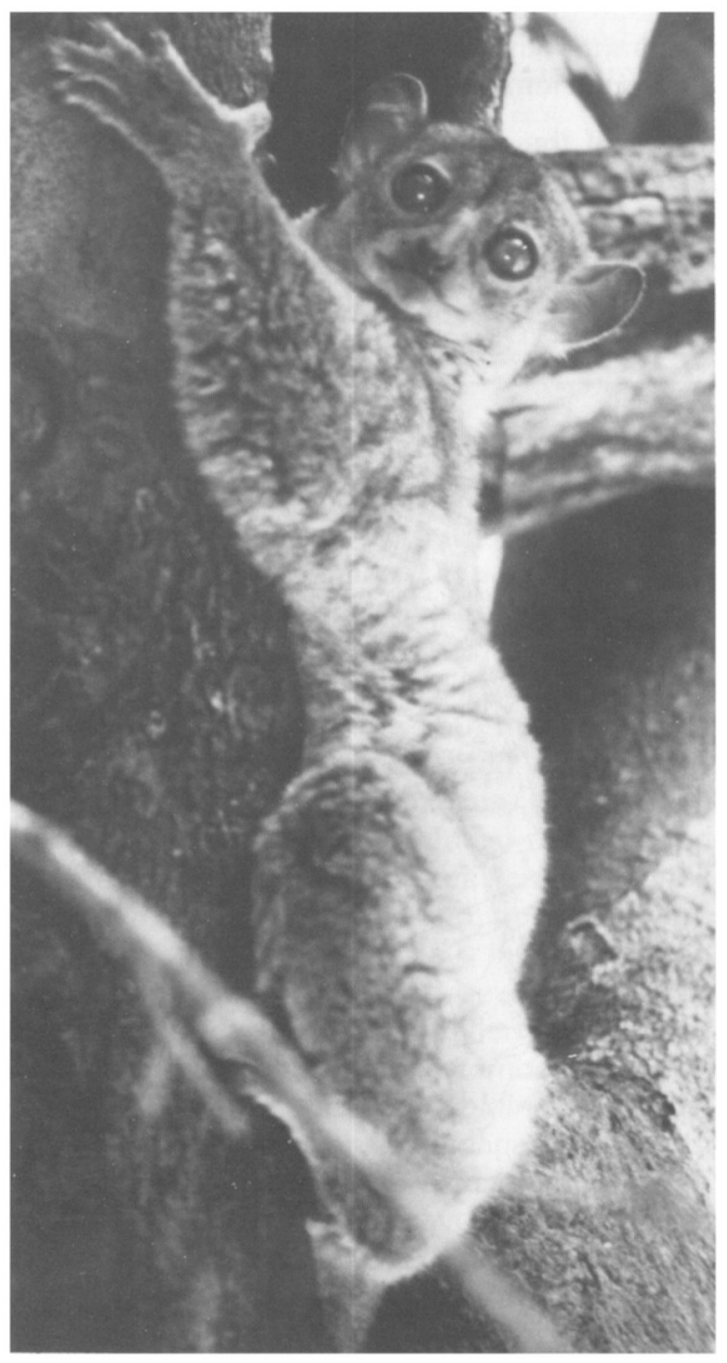

Sportive lemur at Ankarana (Jane Wilson). 
potto or the South American Choloepus than any of the extant lemurs. An Archaeolemur skull was found at Ankarana by French cavers recently (Peyre et al., 1982). This, one of the largest lemurs to have lived, probably occupied a baboon-like niche (Vuillaume-Randriamanantena and Ralaiarison-Raharizelina, 1987). We also collected a bone from an as yet unidentified lemur.

Although lepilemurs and crowned lemurs are common in the forests close to the cave entrance, they are absent from the rich skeletal remains inside. We wonder whether all 11 lemur species (five sub-fossils and six living) ever coexisted at Ankarana-the niches each would have filled differ sufficiently for them to avoid competition.

Some of the $H$. simus skeletons looked quite recent, not having undergone the early stages of

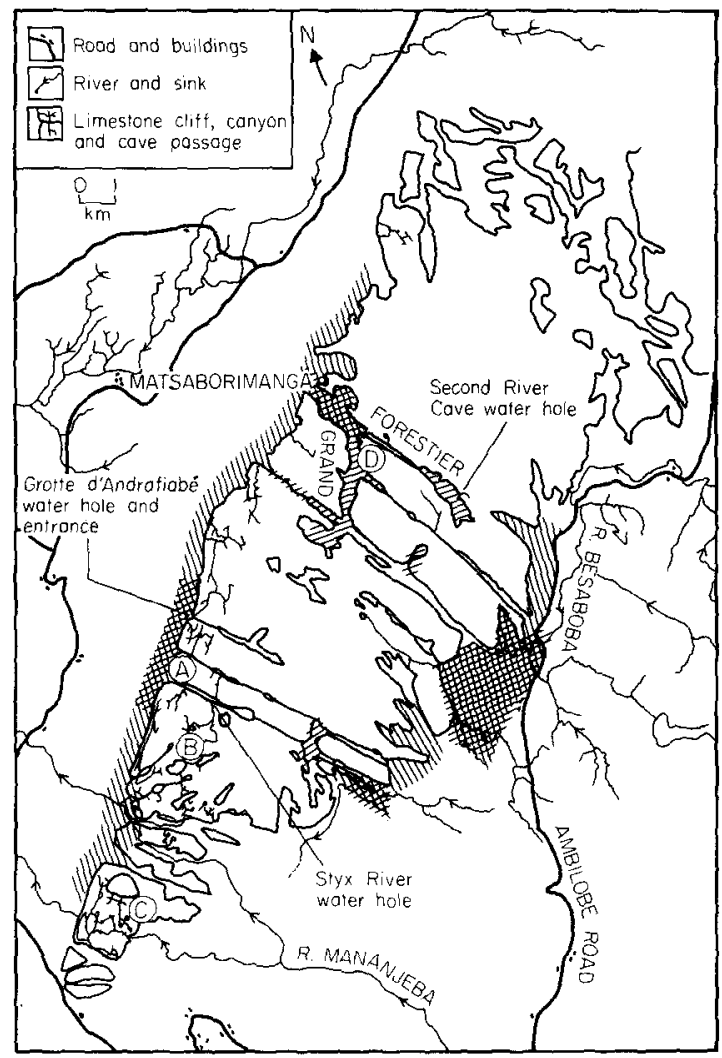

Figure 3. Map of Ankarana showing approximate distribution of $L$.f. sanfordi and ( $L$.

coronatus. (A) Andriafiabé cave (sub-fossil finds),

(B) Styx River Cave, (C) Crocodile caves, (D) Base camp. fossilization of earlier finds. There is the exciting possibility that a second population of greater bamboo lemur lives on in some remote comer of the little-known Ankarana reserve. There is certainly plenty of bamboo (its food plant at Ranomafana) available and there is evidence that a lemur is eating it. Sadly, we ran out of time before we could thoroughly search all the bamboo patches we found at Ankarana. But if $H$. simus does live here, it is protected to some extent by Ankarana's formidable terrain.

\section{The aye-aye?}

Another interesting but puzzling observation in the Ankarana forests was of gnawed conical holes in tree trunks, typically $8 \mathrm{~cm}$ wide and $5 \mathrm{~cm}$ deep with $2-3-\mathrm{mm}$ wide tooth marks. The only likely candidate responsible for such damage is the ayeaye Daubentonia madagascariensis (J.I. Pollock pers. comm., 1987), and further credence is given to this suggestion by the recent observation of aye-aye at Andasibé (Perinet) gnawing a $4 \times 4 \times 1 \mathrm{~cm}$ hole in a tree, presumably to obtain food (Ganzhorn and Rabesoa, 1986). An ayeaye has been seen at Ambilobé, less than $20 \mathrm{~km}$ from where we saw these holes (Petter, 1977). The aye-aye would be Ankarana's twelfth lemur species*.

\section{The forest and its fauna}

The forest types that support the lemurs are determined by water availability and, to a lesser extent, by whether the substrate is basalt or limestone. The massif is irrigated by a system of large subterranean rivers and the lushest forest grows above these (Figure 3 ). In the wet season some canyons are flooded to a depth of $30 \mathrm{~m}$ and here the forest is dominated by a single leguminous tree Mezonovium sp. (which, interestingly, is found as a drought-adapted thorny vine form on the tsingy). Forest types range from this to rich closed canopy forest and these varied habitats support a diverse fauna. For example, we counted 64 bird species (of 32 families) of which 78 per cent are endemic, accounting for one-third of all breeding birds of Madagascar. We also recorded 55 species of butterflies, of which *During September 1987 (after this paper was written) P.D. Stewart saw an aye-aye in the main canyon forests near the 1986 base-camp at Ankarana.

Oryx Vol 22 No 3, July 1988 
34 are endemic species, 11 are endemic subspecies and only 6 are widespread in the Afrotropical region. Many of the endemic butterflies are restricted to canopy forest and one nymphalid, Apaturopsis kilusa, is a particularly rare and little-known species $(\mathrm{R}$. Vane-Wright pers. comm., 1987), found only in the forests of north-west Madagascar (D'Abrera, 1980). Other animal groups proved to be as rich, but as many are not well studied and catalogued, they are taking longer to identify. Our collections are yielding many species that are new to science.

\section{Mesites}

Under most areas of unbroken canopy there is a layer of dry leaf-litter 2-10 cm deep. The insects within provide food for the rare white-breasted mesite Mesitomis variegata, a representative of the endemic family, Mesitornithidae. This $20-\mathrm{cm}-$ long thrush-like bird has only ever been recorded from three areas: from four tiny forest pockets near Morondava in the west; from the Ankarafantsika reserve; and $350 \mathrm{~km}$ to the north-east at the 'Ankarana cliffs', where three were collected in 1931. As it had not been recorded from Ankarana since 1931 we were delighted to discover that this mesite is abundant in undisturbed forest at Ankarana although absent from open or degraded forest. They are commonly seen in pairs scrabbling in the litter, often with an attendant drongo Dicrurus forficatus, which swoops down on insects flushed out by the mesites. Mesites have impressively strong pair-bonding, but are otherwise unspectacular brown birds. Their great reluctance to fly, and their freezing response to perceived danger, means that they probably would be at great risk should rats or feral cats or dogs become established at Ankarana. However, the local tree felling is probably a greater threat to their survival.

\section{Tsingy}

Only metres above the canopy forests is a harsh xerophytic zone. Some drought-resistant plants (for example Pachypodium sp., and other cactuslike forms) manage to grow in cracks in the bare limestone, their roots penetrating more than $10 \mathrm{~m}$ in search of water, sprawling from their bulbous water-storing bases out over the parched tsingy.

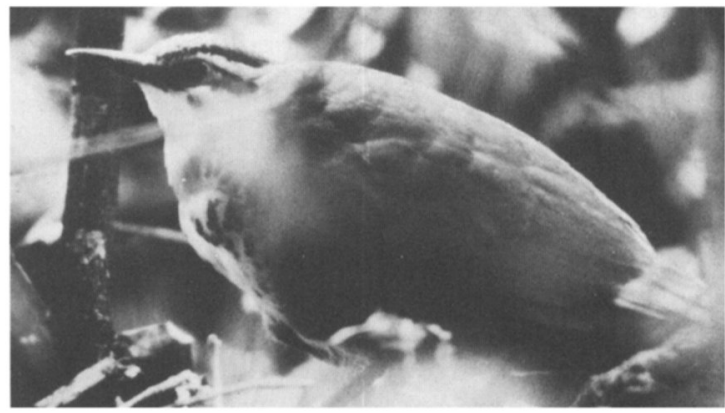

White-breasted mesite (Paul Stewart).

In some places a few full-sized trees can grow (often with stag's-horn ferns, orchids and other epiphytes), but there is little shade and at midday the limestone is uncomfortably hot to touch. Crowned lemurs are seemingly unperturbed by sharp limestone, harpoon burs and thorny vegetation; they climb up here to travel to the next forest patch or browse on the few tiny fleshy fruits of plants such as Ficus spp., Noronhia sp. and Pandanus spp.

\section{Second River Cave}

The Second River Cave, only $3 \mathrm{~km}$ but five hours on foot from the savannah outside Ankarana, is worthy of a special mention (Figure 3). It contrasts with the 11-km Grotte d'Andrafiabé dry cave system described by Wilson (1987). Andrafiabé is rich in cave-adapted terrestrial invertebrates and guanobious insects but the 150-m long Second River Cave has various specialized blind aquatic species. It is also of interest because after $10.00 \mathrm{~h}$ the water inside is illuminated by daylight and so forest animals can see sufficiently to drink there. Troops of crowned lemurs have worn rocks smooth on their journeys inside there on most afternoons during the dry season. The vontsiry or Madagascar ring-tailed mongoose Galidia elegans, wild pigs Potamochoerus larvatus and even kingfishers Ispidina madagascariensis also visit the area. Madagascar's largest carnivore, the fosa Cryptoprocta ferox, was seen several times close to the cave, the grey fur of the crowned lemur in its faeces is witness to the fact that this is a good place for it to hunt. Although the fosa looks like a cat, it is actually a large ferret (Viverridae) and sole representative of the endemic subfamily Cryptoproctinae. It 
grows to a length of nearly a metre excluding the equally long, horizontally held tail.

Detritus brought into the cave by floods and cave roosting swifts and bats, Miniopterus minor manavi and Miniopterus inflatus africanus, ultimately provide food for the various troglobitic (cave-adapted) animals such as a new species of blind centipede, which is yet to be given a scientific name. Even in the daylight-illuminated part of the cave, as yet unidentified blind white shrimps thrive in greater numbers than their sighted cousins. Deeper in, some in a pool glazed over with a 2 -mm layer of calcite, two new species of sighted fish live despite any obvious source of food. Presumably these Glossogobius spp. arrived in the cave (just as their next meal will arrive) with wet season flood waters.

The most exciting find from the Second River Cave was a new eyeless goby, which is yet to be named (K. Banister, pers. comm., 1987) but may prove to belong to a new genus or even a new family. These cave-adapted fish are white and are about twice the size $(7 \mathrm{~cm})$ of the pigmented gobies. Presumably they have evolved comparatively recently from normal freshwater species, unlike Madagascar's two known troglobitic fish, which are isolated under desert in the caves of the south-west. All 39 known species of troglobitic fish are endangered. This new species is almost certainly endemic to the Ankarana Massif and should also be considered endangered.

\section{Crocodiles}

Nile crocodiles are still quite abundant in the subterranean rivers of the southern massif, despite the fact that they are hunted there each OctoberNovember, at the end of their period of aestivation. Reports of individuals up to $6 \mathrm{~m}$ long have been made by reliable observers ( $\mathrm{J}$. Radofilao, pers. comm., 1986) making Ankarana one of the few places in the world where crocodiles of this size can still be seen. Crocodile skins are much in demand in Madagascar's capital, Antananarivo. At a recent Friday Market (Zoma) one of us (P.D.S.) counted over 1000 crocodile items (brief-cases, handbags, stuffed hatchlings etc.) accounting for at least 300 individuals of all ages, many having been killed before achieving breeding size. Interestingly most crocodile 168 products were made from dorsal skin. Presumably the valuable belly skin is exported.

It is difficult to reconcile the apparent abundance and fast turn-over of crocodile products with a recent statement that the crocodiles' only refuges in Madagascar are 'confined to a few regions where access is difficult, such as the subterranean rivers of Ankarana or . . . in a few sacred lakes like Lake Anivorano' nearby (Blanc, 1984). We heard mention of 'crocodile farms' but those we visited turned out to be one or two small tanks containing fewer than 10 individuals. Anecdotal evidence implies that crocodiles are still thriving in Mahjangha province (perhaps there is even a large crocodile farm there) and the Medicin Inspecteur (doctor) of Morondava told us of a woman who had been taken by a crocodile in 1986 while she was washing in the river Tsiribihina in western Madagascar.

\section{Bats}

Another cave-frequenting species not protected by fady is the large $(60-\mathrm{cm}$ wingspan) fruitbat Eidolon helvum dupraneum. These roost in canyon alcoves and in their thousands in those Ankarana caves that have large entrances. They are probably the 'Rousettus' bats that Paulian (1981) describes as being smoked out of the caves. S.V.F. and other expedition members visiting the more accessible eastern Ankarana caves that are close to the tarmacked Antsiranana to Ambilobé road, noted evidence of this unhappy activity. Long flexible poles are waved about amongst the disturbed bats in order to knock them down. This hunting appeared to be local and small-scale, and the technique used so inefficient, that healthy bat populations will probably survive at sustainable levels. Fruit bats are reputedly good to eat and are said to be tastier than lemur meat!

The smaller insectivorous bats are not persecuted and there is a varied bat fauna. The most striking is Triaenops persicus rufus. The genus is characterized by the trident on the nose, and Trianeops furculus, which also occurs at Ankarana, has the longest trident of all.

\section{Exploitation of the forest}

Until recently, ecologists believed that before Oryx Vol 22 No 3, July 1988 


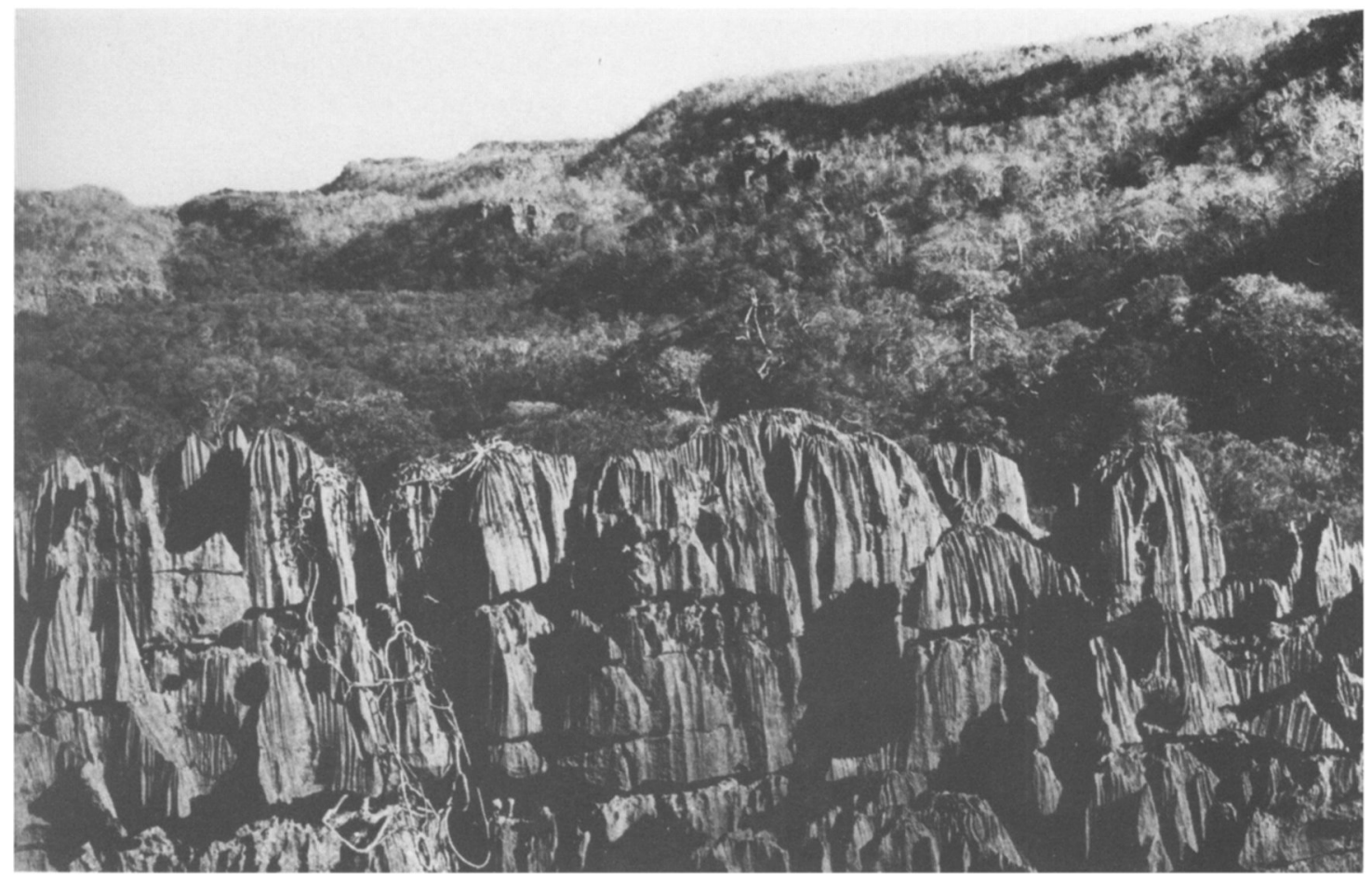

View from above the Second River Cave (Jane Wilson).

man's arrival, perhaps 2500 years ago, most of Madagascar was completely covered in forest (see Durrell, 1986, for example) and many supposed that the savannahs of Madagascar, like that surrounding Ankarana, were also once forested. However, recent research is showing that this traditional view of a forested Madagascar may be inaccurate and that at least some areas were originally savannah with clumps of trees and patches of scrub (MacPhee et al., 1985). It is difficult to be sure what Ankarana used to be like before the influence of man. The secondary forest and scrub nestling in the shelter of the massif's 200-m cliffs, in shallow depressions or in dry river beds, could be perceived as remnants of original forest that has been cleared by man. Fire may have been responsible for some forest destruction and regeneration subsequently limited by cattle grazing. Burning to stimulate better grazing certainly still goes on locally, although fortunately, goats (the Gengis Khan of nature conservation) are not kept in the area.

The small local human population (whose staple Ankarana-a rediscovered nature reserve is rice) living on the savannah close to Ankarana is unlikely to be entirely to blame for the lack of forest there. It seems customary, and is perhaps easier, to blame all Madagascar's environmental problems on slash-and-burn agriculture (which does not occur in the Ankarana region) and ignore the biggest present threat to Madagascar's few remaining forests: commercial clear-felling-in some instances timber extraction is sanctioned by poorly paid officials who are unable to see other ways of making a living (see also Pollock, 1986). Whatever the explanation for the lack of forest cover at Ankarana, the availability of water and the activities of timber fellers are now the most important factors determining where forest still survives.

During the 1940s tracks were cut into Ankarana's forested canyons for commercial timber exploitation, and the subsequent vehicle and bullock cart access allowed selective tree extraction. Villagers and small-scale commercial timber cutters continue to take trees. Although clear-felling has not been practised in the richest central 
canyon canopy forest, few large, and no valuable, trees remain in these accessible canyons. Clear-felling is going on in the north of the massif, but one observer (J. Radofilao, pers. comm., 1986) claims that the forest is actually expanding in other areas. The forest edge along the Ankarana wall is certainly little changed from that to be seen on aerial photographs taken in 1949, although these do not differentiate well between primary forest and secondary scrub. Influential foreign species (e.g. Tamarindus indica) are now present, and in places the canopy structure is broken and ill-defined because of tree extraction; this allows bamboo to sprout opportunistically, excluding species such as the mesite. Stands of mature bamboo (often an indication of forest degradation) are also evident in regions untouched by man. Perhaps disturbance of the forest by the dramatic annual floods has allowed it to take over.

\section{The future}

For the moment the outlook for much of the Ankarana's wildlife, particularly its lemurs, is reasonable. Crowned and Sanford's lemurs are tolerant of selective tree extraction and both species were found where there is constant human disturbance. The fact that the massif's forests have been isolated from more extensive forests for at least 50 years implies that the present forests may be sufficiently large to conserve viable independent populations of the surviving lemur species, although Newmark (1987) suggests further extinctions might be expected in an ecological island like Ankarana. The tiny areas of fruit-rich canopy forest at Ankarana seem to provide food to enable the diurnal lemurs to survive the long dry season. Lemurs are found in huge densities in such forests. The worry about this natural larder is that it is an accessible area, which could be clear-felled in a few weeks. Such a clearance would threaten a significant proportion of the world's remaining crowned lemurs.

At present, everyone entering the nearby Montagne d'Ambre National Park needs a (free) permit from the Direction des Eaux et Forêts at Antsiranana or Antananarivo and this is checked before entry to the reserve is permitted. However, lemurs are still hunted there and the forest is suffering from the activities of people who live 170 within the reserve. Ironically, the lemurs of Ankarana are better protected in their forest, which is unwardened and which few people appreciate has Special Reserve status. At present, then, Malagasy tradition is a more powerful conservation force than legal protection. But as the strength of Malagasy fady against killing lemurs weakens, as it already has in Montagne d'Ambre, the lemurs of Ankarana's accessible edge forests and major canyons will probably disappear. If this happens the populations in the inaccessible moist canyons and collapses may not be large enough to survive.

\section{Acknowledgments}

We are indebted to the Malagasy authorities for permission to conduct this survey and to Drs Lee Durrell and Alison Richard for advice, contacts and help. The work reported here was carried out by the authors and the other members of the 1986 Crocodile Caves of Ankarana Expedition: Phil Chapman, Dave Checkley, Anne Denning, Sheila Hurd, Maggie Hutchings, Mick McHale, Jean Radofilao, Guy-Suzon Ramangason, Jean-Elie Randriamasy, Roo Walters, Ben Gaskell, Sally Crook and Dave Clarke also assisted with the field work.

The project received funding from the Royal Geographical Society (British Sugar Award), British Ecological Society, Smith Kline and French, Duke of Edinburgh Trust, Scientific Exploration Society, John Spedan Lewis Trust, British Museum (Godman Fund), Twenty-Seven Foundation, Sports Council, Ghar Parau Foundation, and Royal Botanic Gardens, Kew (for seed collections). Sir Peter Scott kindly acted as our patron and Dr Peter Edwards (Biology Department, University of Southampton) and the late Dr G.T. Jefferson acted as academic referees. We received approval from the Primate Society and the academic support of the Universities of Southampton, Hull and Wales. The following companies were especially generous in supplying their products: AJBB Plastics, Alcan, Alexandra Workwear, Bayer, BDH, Berk, Boots, BTR Boots, Carton Industries, Caving Supplies, Chance Propper, CPL films, Daisy Root Boots, Dearlove, Duncan Flockhart \& Co., Endecotts, Fisons, Gold Cross, WL Gore, Hampton Printing, Hanimex, International Freight Forwarders, Itona, Janssen, Kodak, Lederle, Ian Looker, Lyon Equipment, May and Baker, Napp, Nelsons, Oxoid, Paramorr Electronics, Pelling and Cross, Pfizer, Phoenix Equipment, Polaroid, Prestige, Roche, Smith Kline and French, Smith and Nephew, Survival Aids, Vango, Varta Batteries, and Winit Boots.

\section{References}

Andriamampianina, J. 1984. Nature reserves and nature conservation in Madagascar. In Madagascar: Key Environments Series (eds A. Jolly, P. Oberlé and R. Albignac), pp. 219-227. Pergamon, Oxford.

Blanc, C.P. 1984. The reptiles. In Madagascar: Key Environments Series (eds A. Jolly, P. Oberlé and R. Albignac), pp. 105-114. Pergamon, Oxford.

Oryx Vol 22 No 3, July 1988 


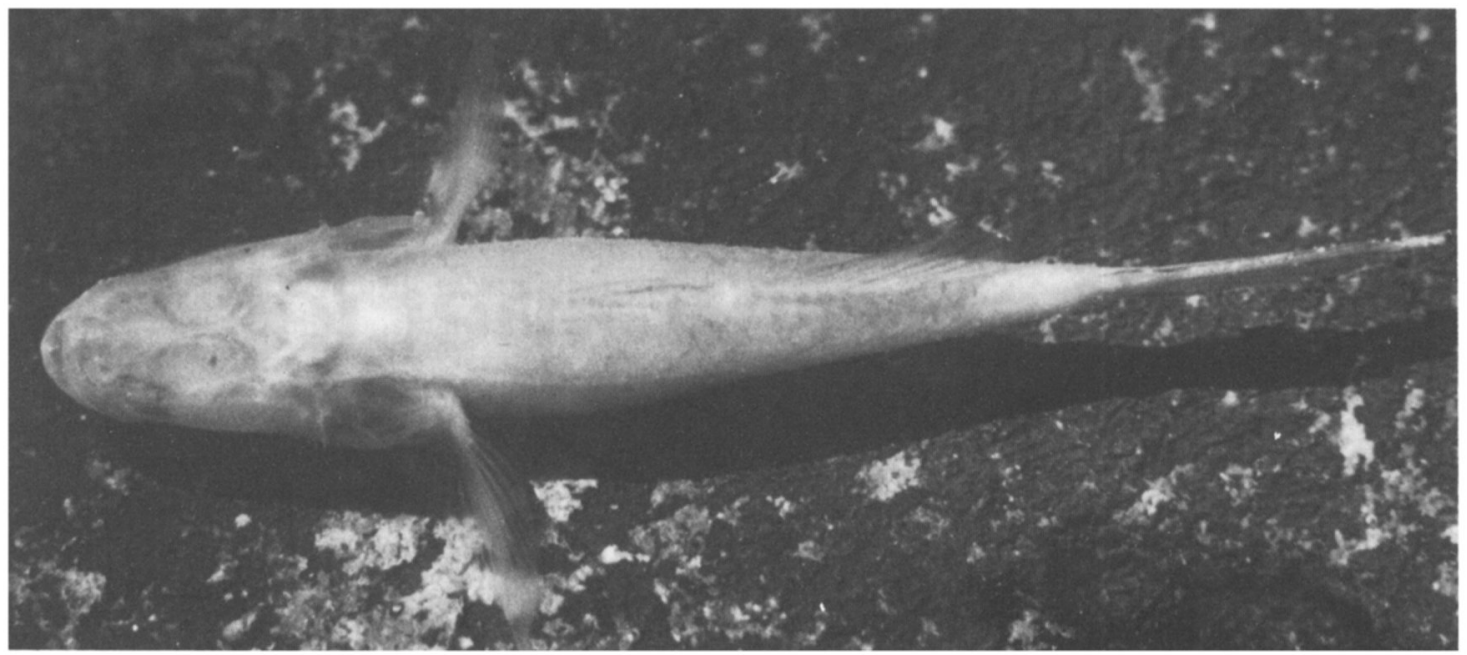

The new species of blind goby from Second River Cave (Jane Wilson).

Bourlière, F. 1985. Primate communities: their structure and role in the tropical ecosystem. Int. J. Primatol. 6(1), 1-26.

Chapman, P., Checkley, D., Fowler, S.V., Hurd, S., Ramangason, G.-S., Randriamasy, J.-E., McHale, M., Stewart, P., Walters, R. and Wilson, J.M. 1987. A survey and management proposals for a tropical deciduous forest reserve at Ankarana in northern Madagascar. Biol. Cons., submitted.

D'Abrera, B.L. 1980. Butterflies of the Afrotropical Region. Lansdowne Press, Melbourne, Australia.

Durrell, L. 1986. Wildlife research in Madagascar: how foreigners are helping. Oryx, 20, 10-14.

Ganzhorn, J.U. and Rabesoa, J. 1986. The Aye-aye, Daubentonia madagasceriensis found in the eastern rainforest of Madagascar. Folia Primatol. 46, 125-126.

MacPhee, R.D.E., Burney, D.A. and Wells, N.A. 1985. Early Holocene chronology and environment at Ampasambazimba, a Malagasy sub-fossil site. Int. J. Primatol. 6, 463-489.

Newmark, W.D. 1987. A land-bridge island perspective on mammalian extinctions in North American parks. Nature, 325, 430-432.

Paulian, R. 1981. Les Mammifères: vestiges d'un monde disparu. In Madagascar, Un Sancuaire de la Nature led. P. Oberlé), pp. 75-94. Lechavalier, Paris.

Petter, J.J. 1947. The aye-aye. In Primate Conservation (eds Prince Rainier of Monaco and G. Bourne). Academic Press, New York.

Petter, J.J., Albignac, R. and Rumpler, Y. 1977. Faune de Madagascar 44: Mammifères Lémuriens. ORSTOM/ CNRS, Paris.

Peyre, J.C., Arthaud, G., Bessaguet, D., Fulcrand, S., Martin, Y., Radofilao, J., Flandin, J.-M. and Tessier, F. 1982.
Expedition Speleologique: Madagascar 1982. Federation français de speleolgie.

Pollock, J.I. 1986. Primates and primate conservation priorities in Madagascar. Oryx, 20, 209-216.

Robinson, J.G. and Redford, K.H. 1986. Body size, diet and population density of Neotropical forest mammals. Am. Nat. 128(5), 665-680.

Tattersall, I. 1982. The Primates of Madagascar. Columbia University Press, New York.

Vuillaume-Randriamanantena, M., Godfrey, L.R, and Sutherland, M.R. 1985. Revision of Hapalemur gallieni, Folia Primatol. 45, 89-116.

Vuillaume-Randriamanantena, $M$. and RalaiarisonRaharizelina, R. 1987. Prospection paléontologique dans l'Ankarana. Rapport préliminaire. Paper presented to Academie Malagâche on 16th October 1986 and in press with Bull. Acad. Malagâche.

Wilson, J.M. 1987. The crocodile caves of Ankarana, Madagascar. Oryx, 21, 43-47.

Wilson, J.M., Stewart, P.D., Ramangason, G.-S., Denning, A.M. and Hutchings, M.S. 1988. The ecology and conservation of the Crowned Lemur. Lemur coronatus, at Ankarana, Northern Madagascar with notes on sympatric and sub-fossil lemurs. Folia Primatol, in press.

J.M. Wilson, 6 Sparrow Farm Road, Ewell, Epsom, Surrey KT17 2JL, UK

P.D. Stewart, Biology Department, University of Southampton, Southampton SO9 5NH, UK.

S.V. Fowler, Department of Zoology, University College, PO Box 78, Cardiff CF1 1XL, UK. 